USNRDL-TR-847

18 April 1965

\title{
ION-EXCHANGE PROCESSES BETWEEN IMMISCIBLE MOLTEN PHASES
}

by

\author{
R. C. Scheidt \\ E. C. Freiling
}

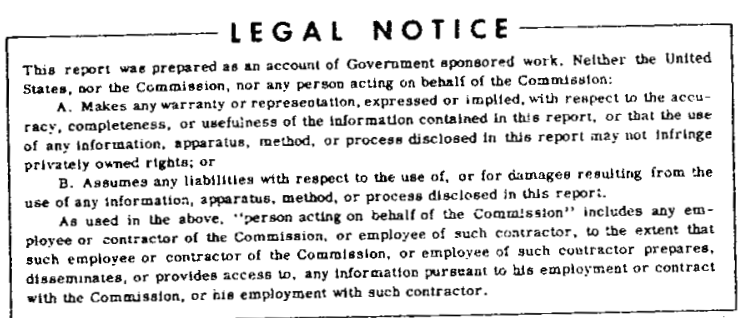

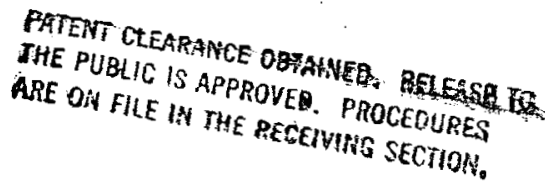

U.S. NA VA L RADIOLOG I CA L

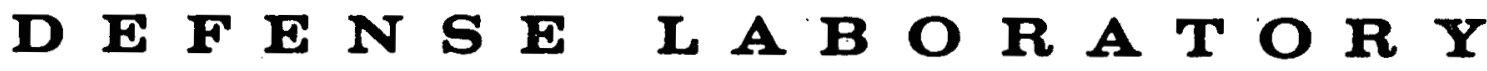
SAN FRANCISCO-CALIFORNIA - 94135 


\author{
PHYSICAI CHEMISTRY BRANCH \\ E. C. Freiling, Head

\section{CHEMICAL TECHNOIOGY DIVISTON \\ R. Cole, Head}

\title{
ADMINISTRATIVE INFORMATION
}

The work requested is part of a project sponsored by the Atomic Energy Commission under Contract No. AT-(49-2)-1167.

\section{ACKNOWLEDGMENTS}

We are grateful to Messrs. Robert Cochran and Robert Brownlee for experimental assistance.

DDC AVAILABILITY NOTICE

Qualified requesters may obtain copies of this report from $D D C$.

Eduard R. Iompleina

Edward R. Tompkins

Associote Scientific Director

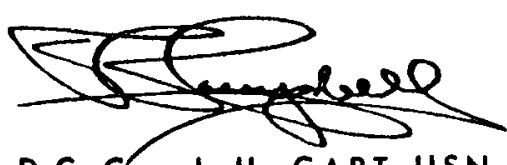

D. C. Campbell, CAPT USN Commanding Officer and Director 


\section{DISCLAIMER}

This report was prepared as an account of work sponsored by an agency of the United States Government. Neither the United States Government nor any agency Thereof, nor any of their employees, makes any warranty, express or implied, or assumes any legal liability or responsibility for the accuracy, completeness, or usefulness of any information, apparatus, product, or process disclosed, or represents that its use would not infringe privately owned rights. Reference herein to any specific commercial product, process, or service by trade name, trademark, manufacturer, or otherwise does not necessarily constitute or imply its endorsement, recommendation, or favoring by the United States Government or any agency thereof. The views and opinions of authors expressed herein do not necessarily state or reflect those of the United States Government or any agency thereof. 


\section{DISCLAIMER}

Portions of this document may be illegible in electronic image products. Images are produced from the best available original document. 
To test the hypothesis that cation distribution in (alkali oxide)(boron oxide)-(alkali halide) systems occurs by ion-exchange processes, some definitive experiments were devised and carried out. The experiments consisted of equilibrating $\mathrm{Na}^{22}$-labelled sodium borate with $\mathrm{KCI}$ at $830^{\circ} \mathrm{C}$. Higher concentrations of $\mathrm{K}^{+}$than $\mathrm{Cl}^{-}$in the borate phase and $\mathrm{Na}^{+}$than $\mathrm{BO}_{2}^{-}$in the salt phase established the operation of cationexchange processes in the immiscible molten system.

\section{This document is}

\section{PUBLICLY RELEASABLE}

$B$ Steete

Authorizing Official

Date: $9.12 .0+$ 
If $\mathrm{Na}^{22}$-labelled sodium borate is equilibrated with $\mathrm{KCl}$ at $830^{\circ} \mathrm{C}$, it is found that the concentration of the foreign cation always exceeded the concentration of the foreign anion in the immiscible phase being considered, i.e., in the oxide phase the concentration of $\mathrm{K}^{+}$exceeds that of $\mathrm{Cl}^{-}$while in the salt phase $\mathrm{Na}^{+}$exceeds the concentration of $\mathrm{BO}_{2}^{-}$. This observation confirms the existence of ion-exchange processes previously postulated to occur in molten alkali halide-alkali borate systems. 
Stalhane ${ }^{1}$ and Dunicz and Scheidt ${ }^{2}$ have studied the miscibility of molten alkali borates with molten alkali halides (except fluorides) in the region $800-980^{\circ} \mathrm{C}$. The ternary systems (alkali oxide)-(alkali halide)(boron oxide) show miscibility gaps in this temperature range at low alkali-oxide contents. Biscoe and Warren, 3 among others, have postulated structures for alkali borate glasses which strongly resemble those of synthetic, organic ion exchangers. Specifically, they are visualized as mobile cations, attracted by coulombic forces to localizations of negative charge, the latter being part of a three dimensional network of covalently bonded atoms.

Adams and Quan ${ }^{4}$ and Krogh-Moe ${ }^{5}$ have further assumed that such structures persist when the glasses are molten. Therefore, current models of liquid borate structure suggest that the immiscible phases of alkali borate are essentially molten ion-exchangers in contact with molten electrolytes. This interpretation is supported by the distribution coefficients of alkali, alkaline-earth, and rare-earth cations reported by Rowell. 6 Rowell's results show that, in certain regions of alkali oxide content, distribution coefficients resemble those obtained between Dowex-50 and dilute $\mathrm{HCl}$, not only in order of selectivity but also in magnitude.

This report first describes an ion-exchange mechanism for the distribution of cations in these systems. It then presents the rationale for testing the mechanism, and finally, presents data to support the proposed interpretation.

PROPOSED MECHANISM

Figure 1 shows a typical miscibility diagram for the systems in question, plotted in terms of components of the type $\mathrm{B}_{2} \mathrm{O}_{3}, \mathrm{MBO}_{2}$ and $\mathrm{MX}$ $(\mathrm{M}=a l k a l i$ metal, $\mathrm{X}=\mathrm{Cl}, \mathrm{Br}$ or $\mathrm{I})$. The important feature $\mathrm{of}$ this diagram 


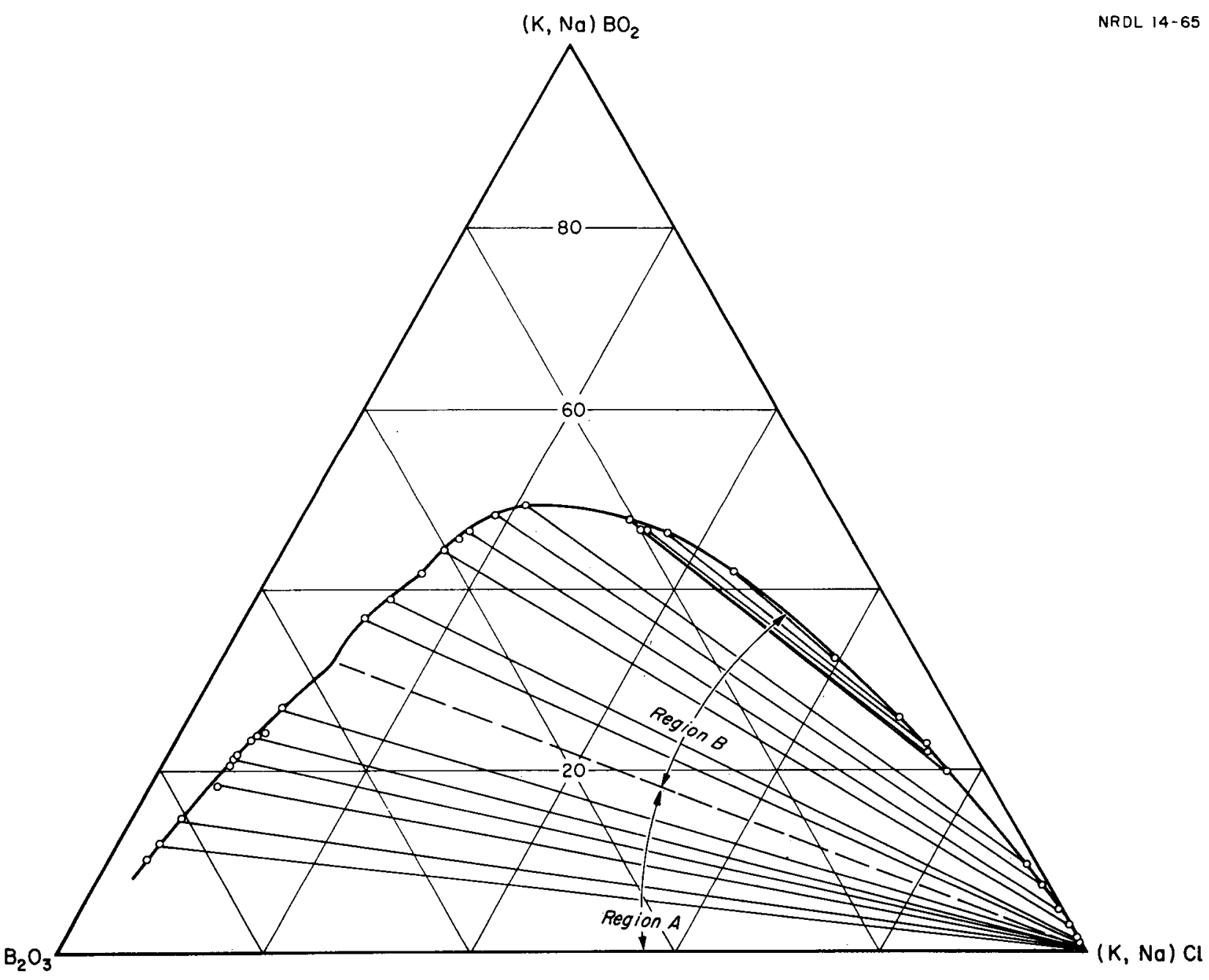

Fig. 1 Compositions Tested for Ion-Exchange Processes $\left(830^{\circ} \mathrm{C}\right.$ ) 
for the subject at hand is that the miscibility gap falls into two regions and this is indicated by both the behavior of the tie lines and the shape of the curve.

For brevity, we will call the region of low alkali metaborate content region $A$. This region extends over borate compositions ranging from pure boric oxide to approximately $\mathrm{M}_{2} \mathrm{O} \cdot 5 \mathrm{~B}_{2} \mathrm{O}_{3}$. In this region there is appreciable alkali halide solubility (i.e., electrolyte penetration) in the oxide (exchanger) phase. The convergence of the tie lines at the alkali halide corner show that the solubility of the oxide (exchanger) in the halide phase (co-phase) is slight. Rowell determined the formula of the soluble species in the sodium chloride system to be $\mathrm{B}_{2} \mathrm{O}_{3}$ and the solubility to be 0.04 mole $\% .6$

Region $\mathrm{B}$ extends from the $\mathrm{M}_{2} \mathrm{O} \cdot 5 \mathrm{~B}_{2} \mathrm{O}_{3}$ composition to the plait point. It shows increasing electrolyte penetration but is characterized better by the sharply increasing borate solubility. In the $\mathrm{NaCl}$ system Rowell found $\mathrm{NaBO}_{2}$ dissolving at compositions more basic than $\mathrm{M}_{2} \mathrm{O} \cdot 5 \mathrm{~B}_{2} \mathrm{O}_{3}$ and polyborate species, such as $\mathrm{MB}_{3} \mathrm{O}_{5}$, at compositions more basic than $\mathrm{M}_{2} \mathrm{O} \cdot 3 \mathrm{~B}_{2} \mathrm{O}_{3} \cdot 6$

In view of these facts the most reasonable mechanism by which ionexchange processes can proceed between the oxide and halide phases in region $A$ appears to be that shown in Fig. 2. Here the convention $\phi$ is used to indicate an oxygen atom shared between two boron atoms, only one of which is indicated. The figure is otherwise self-explanatory. In region $B$ the figure should be modified to show the presence of $\left(\mathrm{M}^{+}\right)$$\mathrm{BO}_{2}\left(\mathrm{~B}_{2} \mathrm{O}_{3}\right)_{n}^{-}$ion pairs and similar structures which arise from the breakdown of the borate stmucture and dissociate in the halide phase.

\section{RATIONAIE}

The foregoing considerations indicate certain differences from the familiar aqueous ion exchange system: there is no neutral phase corresponding to water (or organic solvent); there are no conditions of negligible electrolyte penetration and under most conditions penetration is high; at all compositions, there is a sensible exchanger solubility, and at some compositions this solubility is appreciable. In view of these differences, it is worthwhile clarifying what we mean by "ion exchange" in general before proceeding. 
NRDL $371-64$

OXIDE PHASE

SALT PHASE

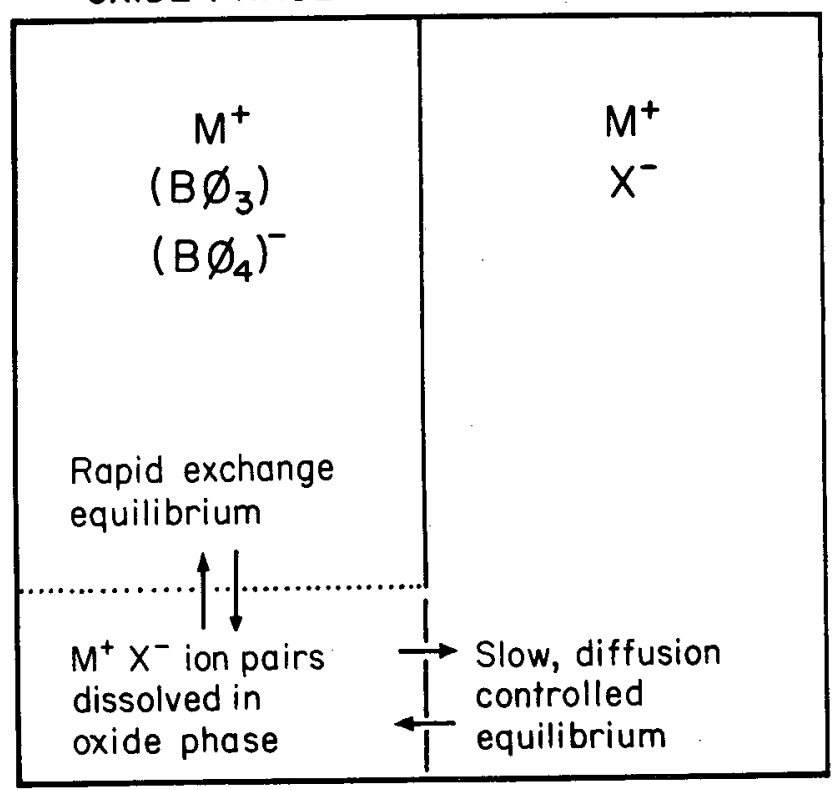

Fig. 2 Postulated Behavior of (Boron Oxide)-(Alkali Oxide)-(Alkali Halide) Systems at Low Alkali Oxide Concentrations. 
There is no definition which has yet received universal acceptance by workers in the field. However, the following set of definitions appear to represent what workers in the field mean in their correspondence:

Ion-exchange mechanism: A mechanism which produces a heterogeneous, ionic metathesis.

Ion-exchange process: A chemical process which proceeds by an ion-exchange mechanism.

Ion-exchanger process: A chemical process carried out by an ion exchanger(e.g., catalysis, ion exclusion, site sharing, etc., including ion-exchange processes).

This definition of ion-exchange mechanism is operational and applicable to any heterogeneous system.

Returning now to Fig. 2, suppose a solute halide $N \times$ is introduced into the salt phase. This can distribute itself between the salt phase and the MX dissolved in the oxide phase according to the equilibrium.

$$
\mathrm{K}_{\mathrm{S}}=\left(\mathrm{a}_{\mathrm{MX}}\right)_{0} /\left(\mathrm{a}_{\mathrm{MX}}\right)_{\mathrm{S}}
$$

where a indicates thermodynamic activity and subscripts $\underline{O}$ and $\underline{S}$ indicate the oxide and salt phases respectively. If this were the only process occurring, the concentration $\mathrm{C}_{\mathrm{N}^{+}}$of $\mathrm{N}^{+}$in the oxide phase would be clearly equal to or less than $G_{x}$. the concentration of $x^{-}$. However, if ion exchange occurs there is the additional equilibrium

$$
K_{I}=\left(a_{N^{+}}\right)_{O}\left(a_{M^{+}}\right)_{S} /\left(a_{N^{+}}\right)_{S}\left(a_{M^{+}}\right)_{O}
$$

This equilibrium permits additional $\mathrm{N}^{+}$to be concentrated in the oxide phase and the possibility that the oxide phase concentration of $\mathrm{N}^{+}$will exceed that of $\mathrm{x}^{-}$. Therefore, a sufficient, but not necessary, condition for proving the occurrence of an ion-exchange process is that

$$
\left(\mathrm{C}_{\mathrm{N}^{+}}\right)_{0}>\left(\mathrm{C}_{\mathrm{X}}-\right)_{0}
$$

The possibility that exchange occur in the salt phase subsequent to dissolution of oxide as $\mathrm{MBO}_{2}$ leads to the same results. If the halide phase consists of pure IX, similar considerations lead to the alternative condition 


$$
\left(\mathrm{C}_{\mathrm{M}^{+}}\right)_{\mathrm{S}}>\left(\mathrm{C}_{\mathrm{BO}_{2}}\left(\mathrm{~B}_{2} \mathrm{O}_{3}\right)^{-}\right)
$$

The experiments described here test the presence of these relationships at various points in regions $A$ and $B$ by equilibrating molten phases of composition $\mathrm{Na}_{2} \mathrm{O} \cdot \mathrm{B}_{2} \mathrm{O}_{3}$ with molten $\mathrm{KCl}$ at $830^{\circ} \mathrm{C}$.

\section{EXPERTMENTAL}

Equilibration charges were prepared from reagent grade chemicals. Sodium borate glasses of known composition were labelled with known quantities of sodium-22, the purity of which had been verified by gammaray spectrometry. Labelled glasses were dehydrated with a Meker burner. Before equilibration, they were further dried for 15 minutes at $900^{\circ} \mathrm{C}$ and then equilibrated with potassium chloride at $830+5^{\circ} \mathrm{C}$. The overall $\mathrm{KCl}$ composition was $54 \mathrm{~mole} \%$ in each case. Equilibrātions were carried out in graphite crucibles under a dry argon atmosphere with mechanical stirring. Equilibrations lasted 95 minutes. The crucible was then removed from the furnace and cooled rapidly in a jet of cold air. Crucibles were sawed open and several samples of each phase were removed for analysis. Samples were analyzed in triplicate. Alkali oxide was determined by titration with $0.1 \mathrm{~N}$ hydrochloric acid to the methyl-red end point. Boron oxide was determined by conversion to mannitoboric acid and subsequent titration with $0.1 \mathrm{~N}$ sodium hydroxide to the phenolphthalein end point. Samples of high sält concentration were analyzed for chloride by the Volhard method. For low salt concentrations, a method using mercuric nitrate and a mixed indicator (bromophenol blue, diphenyl carbazone and xylene cyanole FF in $95 \%$ ethanol) gave more accurate results. Sodium was determined radiometrically and potassium was calculated by difference.

RESUITS AND DISCUSSION

Figure 1 shows the region of the miscibility diagram where each run was carried out. 
Figure 3 shows the values of $\mathrm{C}_{\mathrm{F}^{+}}$and $\mathrm{C}_{1-}$ in the oxide phase for each run. The abscissa in this figure is the mole fraction of $\mathrm{BO}_{2}^{-}$ (regardless of associated cation) that would be present in the oxide phase were no chloride present. This is a convenient measure of position in the miscibility diagram for comparing results between systems containing different alkali halides. The higher value of $\mathrm{C}_{\mathrm{K}^{+}}$in every case clearly established the operation of cation-exchange processes.

The results of Fig. 4 confirm the above conclusion. This figure presents the complementary data for $\mathrm{C}_{\mathrm{Na}}$ and $\mathrm{C}_{\mathrm{BO}}{ }_{2}^{-}$in the salt phase. Again the concentration of the foreign cation exceeds that of the foreign anion for every case.

Finally, it is of interest to compare these data with Rowell's results for the distribution of tracer $\mathrm{Rb}^{+}$and $\mathrm{Cs}^{+}$in the system $\mathrm{Na} 2 \mathrm{O}-\mathrm{NaCl}-\mathrm{B}_{2} \mathrm{O}_{3}$ at $830^{\circ} \mathrm{C}$. Rowell found that, for $\mathrm{Na}^{+}, \mathrm{Rb}^{+}$and $\mathrm{Cs}^{+}$ in region $A$, the larger cation always showed the greater preference for the oxide phase. This situation was exactly reversed in region $B$ : here the larger cation showed the greater preference for the salt phase. Figure 5 shows the distribution data in the present case plotted as

$$
K_{D}=\left(\mathrm{C}_{\mathrm{M}^{+}}\right)_{\mathrm{O}} /\left(\mathrm{C}_{\mathrm{M}^{+}}\right)_{\mathrm{S}}
$$

for $\mathrm{Na}^{+}$and $\mathrm{K}^{+}$. The occurrence of this reversal at the region boundary appears to be coincidental.

The figure shows the same qualitative behavior as that found by Rowell in spite of the increased loading of the exchanger. That is, the larger cation had the greater affinity for the oxide phase in region $A$, but the lesser affinity in region $B$. The occurrence of the reversal at the region boundary appears to be coincidental. 


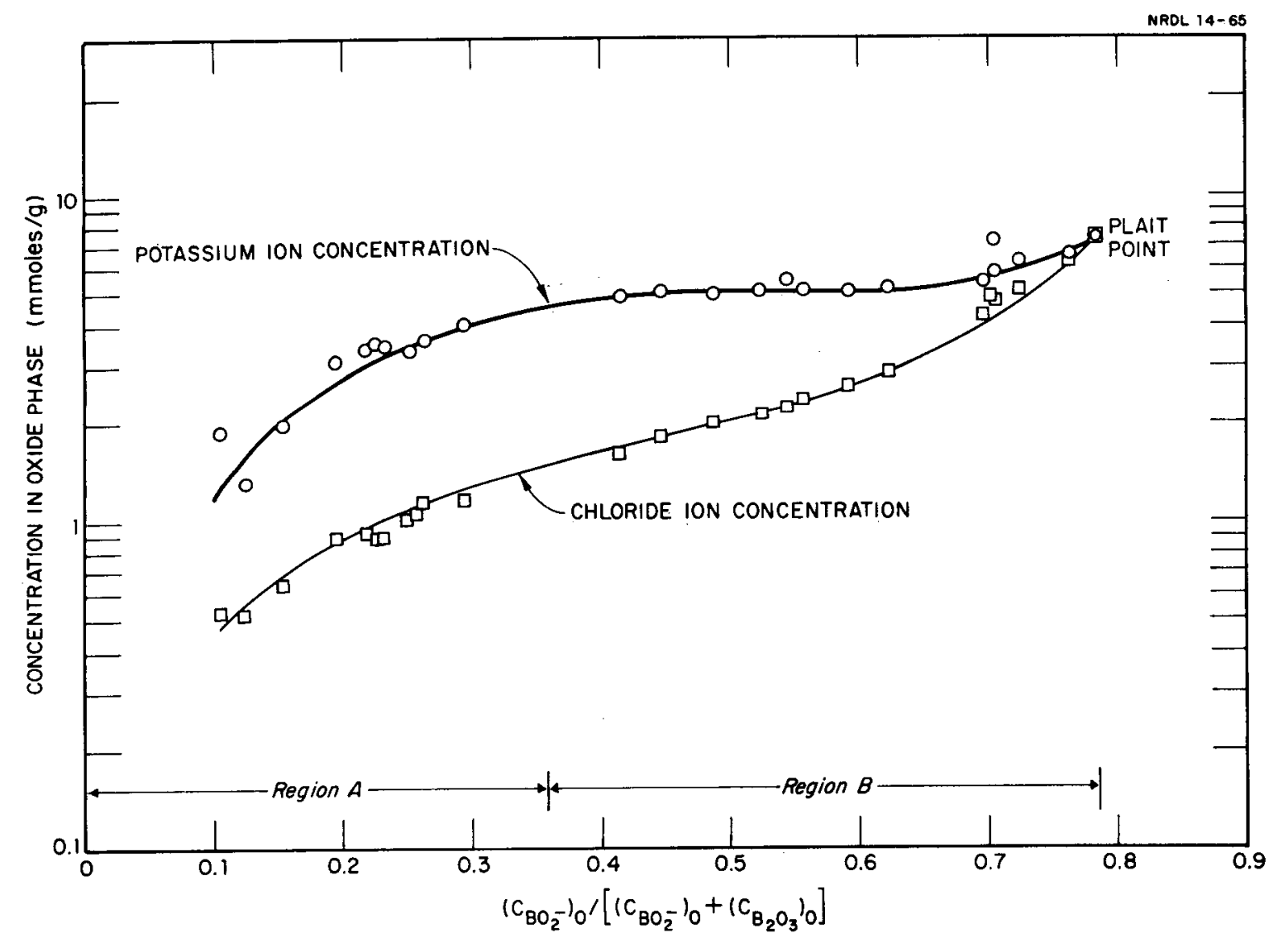

Fig. 3 Concentrations of $\mathrm{K}^{+}$and $\mathrm{Cl}^{-}$Ions in the Oxide Phase $\left(830^{\circ} \mathrm{C}\right)$ 


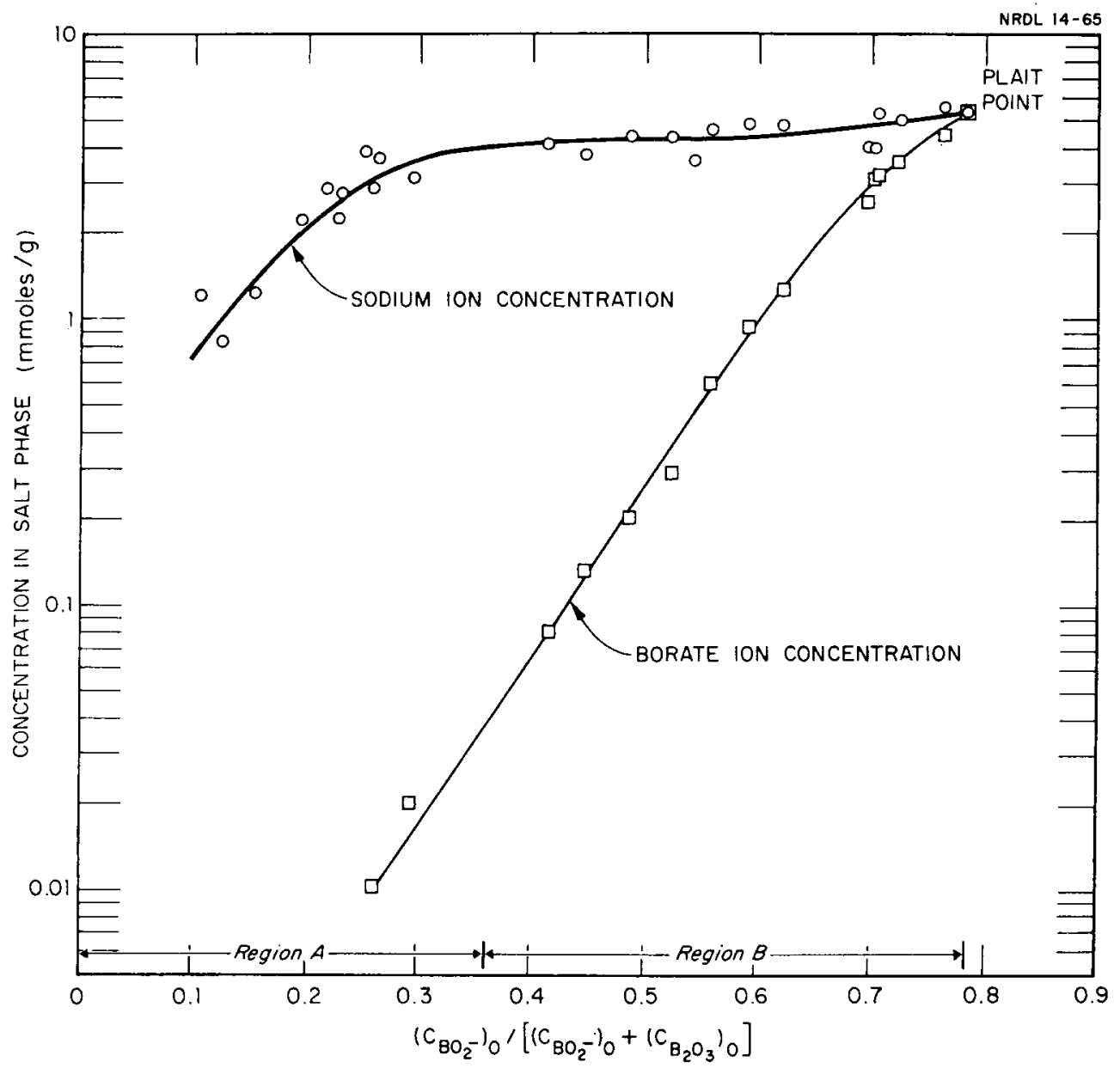

Fig. 4 Concentrations of $\mathrm{Na}^{+}$and $\mathrm{BO}_{2}^{-}$Ions in the Salt Phase $\left(830^{\circ} \mathrm{C}\right)$ 


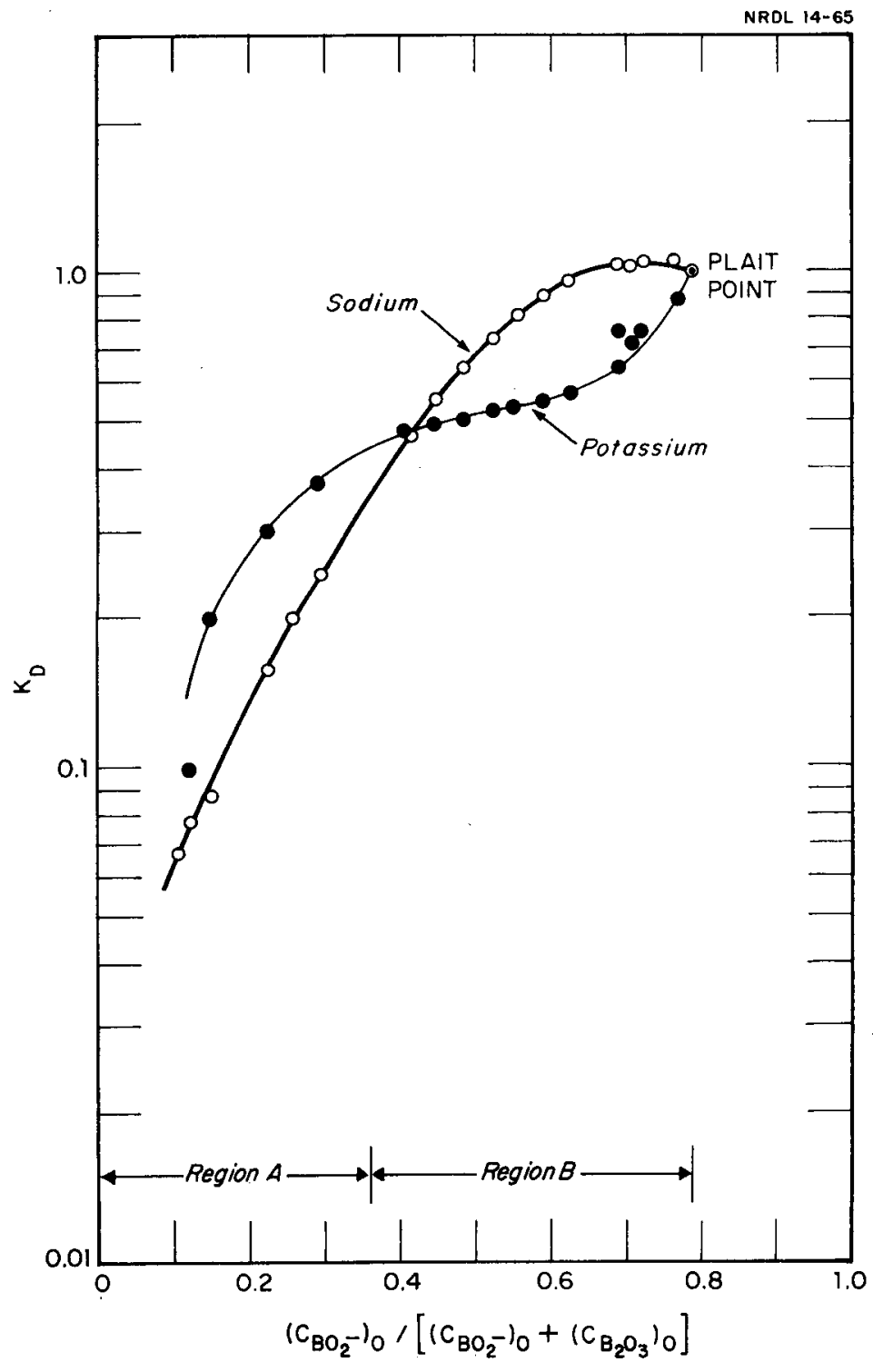

Fig. 5 Distribution of $\mathrm{K}^{+}$and $\mathrm{Na}^{+}$Ions Between Immiscible Phases in the System $(\mathrm{K}, \mathrm{Na}) \mathrm{BO}_{2}-\mathrm{B}_{2} \mathrm{O}_{3}-(\mathrm{K}, \mathrm{Na}) \mathrm{Cl}$ at $830^{\circ} \mathrm{C}$. 
REFERENCES

1. B. L. Stålhane, Z Electrochem., 35; 486 (1929); 36, 404 (1930).

2. B. I. Dunicz and R. C. Scheidt, "Solute Distribution in the $\mathrm{Na}_{2} \mathrm{O}-$ $\mathrm{B}_{2} \mathrm{O}_{3}-\mathrm{NaCl}$ System. III. Immiscibility Diagrams of Molten Sodium Halide-Sodium Polyborates." USNRDL-TR-752, 22 May 1964.

3. J. Biscoe and B. E. Warren, J. Am. Ceram. Soc., 21, 287 (1938).

4. C. E. Adams and J. T. Quan, "Vapor Pressures in the Iiquid System Rb2O$\mathrm{B}_{2} \mathrm{O}_{3}$. Derived Thermodynamic Data and a Structural Interpretation." USNRDL-TR-566, 6 June 1962, to be submitted to J. Phys. Chem.

5. J. Krogh-Moe, Phys. and Chem. of Glasses, 3, 101 (1962).

6. M. Rowell, "Solute Distribution in the $\mathrm{Na}_{2} \mathrm{O}-\mathrm{B}_{2} \mathrm{O}_{3}-\mathrm{NaCl}$ System. I. Alkali Metals." USNRDL-TR-588, 9 Octóber 1962; II. Alkaline Earths and Rare Earths, USNRDL-TR-760, 12 June 1964, to be submitted to $\mathrm{J}$. Inorg. Chem. 

Chemistry

INITIAL DISTRIBUTION

\section{Copies}

NAVY

1 Chief, Bureau of Ships (Codes 320-364A)

2 Chief, Bureau of Ships (Code 210L)

1 Director, Naval Research Laboratory

1 Chief of Naval Research (Code 422)

3 CO, Office of Naval Research, FPO, New York

1 Supt., Naval Postgraduate School, Monterey

1 Commander, Mare Island Naval Snipyard (Library)

ARMY

1 Chief of Research and Development (Atomic office)

1 CG, Army Materiel Command (AMCRD-DE-NE)

1 Commandant, Chemical Center and School

1 Commander, Nuclear Defense Laboratory

$1 \mathrm{CO}$, Engineer Research and Development Laboratory

1 Director, USACDS Nuclear Group

AIR FORCE

1 Director, USAF Project RAND

1 CG, Air Force Special Weapons Laboratory, Kirtland AFB

I Director, Air University Library, Maxwell AF'B

1 Commander, Air Force Cambridge Research Laboratories (CRT)

OTHER DOD ACTIVITIES

2 Director, Defense Atomic Support Agency (Library)

1 Commander, FC/DASA, Sandia Base (FCDV)

20 Defense Documentation Center

AEC ACTIVITIES

3 Argonne National Laboratory 
3 Atomic Energy Commission, Washington

3 Atomic Energy Commission, Division of Research

1 Atomic Energy of Canada, Limited

3 Brookhaven National Laboratory

2 Los Alamos Scientific Laboratory

1 NASA, Scientific \& Technical Information Facility

1 National Bureau of Standards (Library)

1 Sandia Corporation, Albuquerque

1 Sandia Corporation, Livermore

2 University of California Lawrence Radiation Laboratory, Livermore

2 University of California Lawrence Radiation Laboratory, Berkeley

15 Division of Technical Extension, Oak Ridge

USNRDL

35 Technical Information Division

DISTRIBUTION DATE: 25 June 1965 
DOCUMENT CONTROL DATA - R\&D

(Security classiffcation of title, body of abstract and indexing ennotation must be entered when the overall report is clesalfied) 1. ORIGINATIN G ACTIVITY (Corporate author) 2 2a. REPORT SECURITY C LASSIFICATION

U. S. Naval Radiological Defense Laboratory

San Francisco, California 94135 UNCLASSIFIED

3. REPORT TITLE

ION-EXCHANGE PROCESSES BETWEEN TMMISCIBLE MOLTEN PHASES

4. DESCRIPTIVE NOTES (Type of report and inclusivo datoo)

5. AUTHOR(S) (Last name, first name, initial)

Scheidt, Ronald C.

Freiling, Edward C.

\begin{tabular}{|c|c|c|}
\hline 6. REPORT DATE & $\begin{array}{c}\text { 7a. TOTAL NO. OF PAGES } \\
17\end{array}$ & $\begin{array}{c}\text { 7b. NO. OF REFS } \\
6\end{array}$ \\
\hline $\begin{array}{l}\text { 8. CONTRACT OR GRANT No. } \\
\text { CONTract NO. AT- }(49-2)-1167 \\
\text { b. PROJECT No. }\end{array}$ & \multicolumn{2}{|c|}{$\begin{array}{l}\text { 9. ORIGINATOR'S REPORT NUMBER(S) } \\
\text { USNRDL-TR-847 }\end{array}$} \\
\hline $\begin{array}{l}\text { c. } \\
\text { d. }\end{array}$ & 9b. OTHER REPORT NO(S) & other numbers that may be assienod \\
\hline
\end{tabular}

10. AVA IL ABILITY/LIMITATION NOTICES

Qualified requesters may obtain copies of this report from DDC.

11. SUPPL EMENTARY NOTES

12. SPONSORING MILITARY ACTIVITY

Atomic Energy Commission

Washington, D. C. 20545

13. ABSTRACT

To test the hypothesis that cation distribution in (alkali oxide)-(boron oxide)-(alkali halide) systems occurs by ion-exchange processes, some definitive experiments were devised and carried out. The experiments consisted of equilibrating $\mathrm{Na}^{22}$-labelled sodium borate with $\mathrm{KCl}$ at $830^{\circ} \mathrm{C}$. Higher concentrations of $\mathrm{K}^{+}$than $\mathrm{Cl}^{-}$in the borate phase and $\mathrm{Na}^{+}$than $\mathrm{BO}_{2}^{-}$in the salt phase established the operation of cation-exchange processes in the immiscible molten system. 


KEY WORDS
Fused salt
Molten salt ion exchange
Immiscibility diagram phase equilibrium
Ion distribution

Fused salt

Immiscibility diagram phase equilibrium

Ion distribution

1. ORIGINATING ACTIVITY: Enter the name and address of the contractor, subcontractor, grantee, Department of Defense activity or other organization (corporate author) issuing the report.

2a. REPORT SECURTY CLASSIFICATION: Enter the overail security classification of the report. Indicate whether "Restricted Data" is included. Marking is to be in accordance with appropriate security regulations.

2b. GROUP: Automatic downgrading is specified in DoD Directive 5200.10 and Armed Forces Industrial Manual. Enter the group number. Also, when applicable, show that optional markings have been us ed for Group 3 and Group 4 as authorized.

3. REPORT TITLE: Enter the complete report title in all cepital letters. Titles in all cases should be unclassified. If a meaningful title cannot be selected without classification. show title classification in all capitals in parenthesis immediately following the title.

4. DESCRIPTIVE NOTES: If appropriate, enter the type of report, e.g., int erim, progress, summary, annual, or final.

Give the inclusive dates when a specific reporting period is covered.

5. AUTHOR(S): Enter the name(s) of author(s) as shown on or in the report. Enter last name, first name, middle initial. If rilitary, show rank and branch of service. The name of the principal atathor is an absolute minimum requirement.

6. REPORT DATE: Enter the date of the report as day, month, year; or month, year. If more than one'date appears on the report, use date of publication.

7a. TOTAL NUMBER OF PAGES: The total page count should follow normal pagination procedures, i. e., enter the number of pages containing information.

7b. NUMBER OF REFERENCES: Enter the total number of references cited in the report.

8a. CONTRACT OR GRANT NUMBER: If appropriate, enter the applicable number of the contract or grant under which the report was written.

$8 b, 8 c, \& 8 d$. PROJECT NUMBER: Enter the appropriate military department identification, such as project number. subproject number, system numbers, task number, etc.

9. ORIGINATOR'S REPORT NUMBER(S): Enter the official report number by which the document will be identified and controlled by the originating activity. This number must be unique to this report.

9b. OTHER REPORT NUMBER(S): If the report has been assigned any other report numbers (either by the originator or by the sponsor), also enter this number(s).

10. AVALLABILITY/LIMITATION NOTICES: Enter any limitations on further dissemination of the report, other than those imposed by security classification, using standard statements such as:

(1) "Qualified requesters may obtain copies of this report from DDC."

(2) "Foreign announcement and dissemination of this report by $\mathrm{DDC}$ is not authorized."

(3) "U. S. Government agencies may obtain copies of this report directly from DDC. Other qualified DDC users shall request through

(4) "U. S. military agencies may obtain copies of this report directly from DDC Other qualified users shall request through

(5) "All distribution of this report is controlled. Qualified DDC users shall request through ."

If the report has been furnished to the Office of Technical Services, Department of Commerce, for sale to the public, indicate this fact and enter the price, if known.

11. SUPPLEMENTARY NOTES: Use for additional explanatory notes.

12. SPONSORING MILITARY ACTIVITY: Enter the name of the departmental project of fice or laboratory sponsoring (pay ing for) the research and development. Include address.

13. ABSTRACT: Enter an abstract giving a brief and factual summary of the document indicative of the report, even though it may also appear elsewhere in the body of the technical report. If additional space is required, a continuation sheet shall be attached.

It is highly desirable that the abstract of classified reports be unclassified. Each paragraph of the abstract shall end with an indication of the military security classification of the information in the paragraph, represented as (TS), (S), (C), or (U).

There is no limitation on the length of the abstract. However, the suggested length is from 150 to 225 words.

14. KEY WORDS: Key words are technically meaningful terms or short phrases that characterize a report and may be used as index entries for cataloging the report. Key words must be selected so that no security classification is required. Identifiers, such as equipment model designation, trade name, military project code name, geographic location, may be used as key words but will be followed by an indication of technical context. The assignment of links, rales, and weights is optional. 